\title{
Waking Up in Prison: Critical Discussions Between Typical College Students and Their Incarcerated Peers
}

\author{
TABITHA DELL'ANGELO \\ The College of New Jersey, Ewing, NJ, USA
}

\begin{abstract}
This article describes a typical college course that was taught in a youth correctional facility. The course combined traditional college students and inmates from the prison. Over the course of 15 weeks both groups grew to understand one another and themselves. The article seeks to illustrate the realities related both to fear and success in such an undertaking. This collaborative model between colleges and correctional facilities has promise as a model for prison education.
\end{abstract}

Keywords: Prison education, qualitative analysis, narrative.

The single story creates stereotypes, and the problem with stereotypes is not that they are untrue, but that they are incomplete. They make one story become the only story. -Chimamanda Ngozi Adichie

\section{Introduction}

I have been teaching at a small liberal arts college in the United States for seven years. My students are preparing to become teachers and they fit the dominant mold of pre-service teachers - they are largely female, white, middle class, Christian, heterosexual, nondisabled, and their own schooling experiences have been very monocultural. My specific program focus is preparing teachers to work in under resourced schools. That focus has attracted a small population of students to my program who do not fit the mold previously described. Therefore, the students in my courses are often more diverse than the general student population at the college. A few semesters ago I had the opportunity to teach one of these classes in a youth correctional facility. Each week 15 students from my college and I would drive to this prison and hold class with 15 inmates. We read the same material and did similar assignments to the on-campus class.

This paper will discuss how the group dynamics supported growth for both the inmates and the typical college students. I expected resistance from both groups. Martinson's (1974) skepticism that rehabilitation is possible with the inmates was one reality. The typical college students were largely coming from very monocultural, middle class backgrounds, and expecting them to make big strides in their ideas about the inmates was also unlikely. In this essay, I will discuss what I learned about listening and responding to resistance around issues of privilege in the process of teaching this course and how that has translated into all of my typical on campus classes.
I was teaching a course called Introduction to Urban Education. In that course we study policies that impact schools, children, and families as well as spending a substantial amount of time engaged in critical selfreflection. It is important for all of my students, no matter their cultural background, to think deeply about why they are choosing to teach in schools where the children struggle everyday with the implicit and explicit messages that they are less valued than their peers at schools in the neighboring town. These messages arrive at every level. The schools and classrooms are often working with very limited resources, the teachers are under a great deal of pressure to increase test scores, the surrounding neighborhoods are sometimes too unsafe to allow children to play outside, and children need only to watch any television show to see that their school experience is different from many others. As my students prepare to teach "other people's children" it is imperative that they explore their own cultural identity and motivation for choosing this path in education.

About half-way through the semester one of my students told me about another program on campus - a prison outreach and education program. She was excited and said that I should volunteer to teach at the prison. My immediate reaction was positive, but not because I was excited about teaching in prison but rather because my student suggested it to me. I mention this fact because I recognize that even though I teach this course and try to facilitate self-discovery in my students, I am also acutely aware of how much I also need to constantly engage in critical self-reflection. In that moment my focus was on me, the idea that my student liked me, thought I had something to offer, associated me with the kind of person who would teach in a prison. The semester ended and I did not pursue this idea any further.

A year later I was still thinking about how I could be

Correspondence: Tabitha Dell'Angelo, Email: dellange@tcnj.edu 
helpful in a prison. I just was not sure. Finally, I decided to meet with the person who directs the prison education program to find out exactly what they did and determine if there was a place for me. After the meeting it was decided that I would take my Introduction to Urban Education course into the prison. The typical college students would have to apply for 15 spots. I left that meeting and immediately started thinking about the course. Unfortunately, it really never occurred to me that I would have to change the course to meet the needs of the inmates. Instead, I was more concerned with logistics. They needed books, materials, etc. Over the next few months there were emails and phone calls. I wanted enough books for all of the inmates and I wanted them to have the first book in advance so they could read it before the first class. For my part, I made copies of articles that would be important in the course and placed them into folders for each inmate that included the syllabus and explanations of assignments.

\section{We're in}

We were lucky enough to have transportation arranged for us. My students would all meet a van each week that would take them to the prison. The college students purchased big blue t-shirts that said "Prison Outreach". They were instructed to have their identification. Without identification they could be turned away. The van had just enough room for the students so I drove my own car and met them there.

A long tree lined road lead to a huge 1930s style building - the architecture seemed to say that this was not always a prison. Hollers and catcalls from various windows greeted us as we approached the door. Through one arched doorway and a small vestibule there was a metal detector to both walk through and a belt through which you put your belongings. The correctional officer assisting us through the security checkpoint greeted us, gave us instructions on getting through the metal detector, and patiently restated instructions for the college students who were too stunned by their arrival at a prison to respond when he asked for identification cards. The metal detector beeped when I went through. A few of my students let out nervous giggles. I immediately knew why it went off and braced myself for the embarrassing moment that was about to ensue. It was my underwire bra. I had been through this during a prior visit but forgot to wear a sports bra today. I had to go back through three times. First, cupping my breasts to try to block the wire from being detected. Then, cupping my breasts and walking through at a snail's pace. Finally, cupping breasts, snail's pace and sideways was the magic combination. I would not forget to wear a sports bra again.

Another correctional officer needed to sign us all in. He was 10 feet away, behind a glass wall, staring at as ominously. Our identification was collected by the officer who worked the metal detector and handed to the burly man behind the glass. He scowled and cursed our group, audibly. The students looked terrified to be in the prison, to be greeted with clear disdain. I was also nervous but I tried to stay light hearted and smile in response to his query, "How many fucking people did you bring with you?" I even tried to joke with the correctional officer to which he responded, "This is a fucking joke;" still I was not sure he actually got my joke. In a journal entry, one student wrote, "I was walking behind you, watching you walk briskly, wondering what you were thinking. You were about to be the bridge between felons and suburban college kids. That was a 'wow' moment for me" (Liz, 9/15).

What Liz and the other students didn't know is that I had no idea what to expect. For as much as I planned, there was still inconsistent communication between the prison and me ahead of time. When I toured the prison a few weeks back, the superintendent and I walked up a flight of stairs and I noticed we were also following a trail of blood. He wanted to show me something that was behind a door but when he looked through the glass he said it was not a good time and we left. On the way out he showed me "where the guys feed;" he was referring to the cafeteria. I wasn't exactly sure what I had gotten myself into.

\section{Class begins}

I arrived with 15 typical college students and expected 15 incarcerated students. When I arrived I had a folder waiting for me from the social worker. There were 19 inmate names on it. I took a deep breath. "A few more students would not normally phase me, this shouldn't be a problem," I thought. Still, it felt like a problem. After we were all signed in, a 30-minute process, we walked through a series of heavy gated doors to the Education Wing. As we turned left, into the Education Wing, the mood of the facility changed a little. The correctional officer stationed at the entrance was all smiles, and welcomed us in. There were inmates there already who were working. They asked if I needed anything for my class, helped me find my books, and offered to move desks for us. I asked them if I would see them each week and they said that this was their job and their shift and they would be there each week. I introduced myself and asked for their names. "Ok, this is going to be OK," I thought.

My 15 students and I filed into the classroom and we arranged all of the chairs in a big semi-circle. We were waiting for the inmates. I told the college students to leave desks open between them so the inmates would have to sit among them and not segregate themselves. I considered writing my name on the board but then decided that was dumb. It seemed like it was taking a long time for the inmates to arrive and I did not know what to do. Do I start teaching without them? I finally decided to just make small talk with the students who were there. It felt like the worst first date ever. Finally, a line of guys in khaki pants and tops started coming in. As each one entered I smiled, introduced myself and asked for their name so I could check them from my attendance. It took me a minute to realize they were giving me last names. Many of them mumbled and I had to ask them to repeat their name several times. One student told me his name, "Fred;" I said 
"Fred?" He repeated, "Redge." "Oh, Redge?" I said. Finally, looking annoyed, he pointed to a tattoo on his neck that clearly said, "Red" as he slowly said, "Reeeed." I could feel my armpits sweating. "I'm so sorry," I said. "Red, of course, Red, welcome Red."

Once everyone was checked in and we decided that some incarcerated students just would not be coming, we got started. We would do an ice breaker just like this was a regular class on campus. I had the students stand up and form two circles, an inner and an outer. Each person would face someone else and we would do a speed dating exercise. I would call out a question and each person had a minute to introduce themselves to their partner and answer the question. Nervous giggles erupted from both the college students and the inmates. Here we go - Tell your partner about the best teacher you've ever had, Tell your partner about the worst teacher you've ever had, Tell your partner what you would do if you hit the lottery... In response to that activity, one student wrote in her journal,

One of the ice breaker questions asked, "What was your favorite/worse teacher?" Right off the bat, James responded that he remembered his favorite teacher and it was his 7 th grade music teacher. I assumed that he liked music and asked him if he played an instrument. He said he didn't do very well in the class but he liked her because the teacher fed him. WOW! My heart broke when I heard that. It made me realize how blessed I am just to have food in my fridge. (Tina, typical student, weekly journal)

The reality of children from low resource homes going to school hungry was something we had discussed in the classes on campus leading up to our time at the prison. Additionally, the traditional college students had watched a lecture with Jeffrey Andrade-Duncan where he talked about this very scenario. Yet, it wasn't until she came face to face with someone who had lived it that it made an impact.

On my way home after that first class I was sure I had made a mistake. I replayed the night and decided there was no way I could do this well. It would be impossible to make this a valuable learning experience for both the typical college students and the incarcerated students. I spent a lot of the ride home trying to figure out how to get out of this obligation. I even thought it would be good if I got in a car accident. If I got hurt or my car was totaled I would have a convenient excuse for why I could not continue. I spent the next few days consumed with thinking about how to balance this course so it was good for everyone. Finally I decided that the typical college students were more interested in being in the prison than learning the course content. I had to let go of the way this class was done on campus. I decided to cut the readings down to the pieces I thought would be most interesting to the inmates; we would still have our speaker and use videos. We would do more in-class writing assignments. And, the biggest decision was to put all of the students in small groups in order to encourage discussion and interaction among the students. To that end, I created "safe houses" in the classroom.
These were small groups of students who would stay together for the entire semester. Pratt (1991) writes about the use of safe houses as "social spaces where cultures meet, clash, and grapple with each other, often in contexts of highly asymmetrical relations of power." Our new groups consisted of about half typical college students and half incarcerated students. Most of the students expressed reservations about this new arrangement.

Cassie [a typical college student] wrote, When we broke up into small groups early in the semester and learned that these groups would be permanent...I was intimidated by the thought that I ould be working with the same group every week.

(Cassie, typical student, weekly journal)

One of her group mates reflected,

My fear when I entered the class is when I saw all the [college] students. I didn't know they was going to be there. I thought I was in the wrong class. I was afraid to talk in a group and as a class but as the class went on I learned how to communicate with others and discuss and argue about different topics. (Chris, incarcerated student, final reflection)

The group members had very different backgrounds and there were power dynamics at play but the students perceived these power dynamics very differently. Cassie's feelings of intimidation about working with the same group every week were context specific. I asked her if she would have felt the same way if this were a traditional on campus class without the inmates. She hesitated and then said that her feeling of intimidation stemmed from the idea of "being forced" to be with the same inmates each week. She said she felt "intimidated" and "fearful," a feeling that she does not associate with being in a group with typical college students. Cassie felt that the inmates had the power in the group.

On the other hand, Chris and some of the other inmates spoke freely about feeling that they were powerless. They were locked up and being watched by correctional officers right outside the door. Chris wrote about feeling "intimidated," the same word Cassie used. Another inmate wrote,

I just wanna thank the [college] students for letting me show them who I am and not what my clothes or situation betrays me as. (Jay, inmate student, final reflection)

I am sure he meant to write "portray" but somehow I felt that writing "betray" might be closer to the reality of what typically happens. Jay's statement also suggests that he may have felt intimidated by the college students and fearful that they would pre-judge him and not give him a chance because he was incarcerated.

\section{Shifts in perspective}

As I planned the course I imagined that the inmate students would have big "aha" moments where they realized the injustices of the public education system in under privileged areas. I imagined that the course content, learning about the social and political realities of public schools, was going to be a great motivator. In 
fact, there were a few of those moments. One of my favorites was following our viewing of parts of Waiting for Superman. We had a heated discussion about tenure. It turned out that none of my students, not even the Education majors, really understood what tenure was before this film. Many of the students from both groups were anxious to talk about the film. Most of the students were feeling that tenure for teachers was not good. Finally, one of the inmate students slapped his hand down on the desk and said, If these teachers can't get fired for nothing then why don't they do everything they think is right for the kids? Why do they keep doing the dumb programs that they don't think are even right? If they don't get fired for doing bad things then why are they scared to do right by the kids? (Will, incarcerated student, class discussion)

Will's statement changed the whole mood of the class. His ability to challenge the group with a reasoned response opened the door to even more open dialogue. All of the students seemed more open to voicing their opinions after that night. After class that night I wrote,

We had a breakthrough tonight. I was feeling great that everyone was talking about teacher tenure and agreeing with one another. Or at least it seemed like everyone agreed. I didn't notice that not everyone was participating. I was just happy there was participation. Then Will, out of nowhere, challenged everyone, even me. He said teachers should use the protections they get from tenure to teach the way they want to teach and to ignore instructional man dates if they think they are bad for their students. This was a brilliant statement. I think some of my Education students wished they would have said it. (instructor journal)

Over the next couple of weeks the discussions in the small groups and in the larger class debriefings were more animated. Everyone seemed to feel more open to sharing ideas. In the final reflections I asked students to discuss how they dealt with disagreements in their groups. Raf shared,

In terms of working with disagreements or conflicts most of them [college students] are very open minded some are just very hard headed. (Rafeal, incarcerated student, final reflection)

I really appreciated this comment because just a few weeks earlier Raf seemed to defer to the college students and accept all of their answers. He almost never offered an opinion that differed. In that same reflection he wrote,

I remember when I first got here...I felt kind of lost, awkward because I've been locked up for a little minute and all the people I really talked to was inmates and officers, so the group kind of show me, remind me what it was like to communicate with regular people. The [small] group we made and the large group discussions contributed to this learning. (Raf, inmate student, final reflection).

Another example of how the context changed the learning dynamics in this course was around the idea of meritocracy. My typical college students knew that they should say that meritocracy was a myth. In regular on-campus classes this did not come easy to them. We might be discussing a situation where working hard clearly did not open doors, and they would defend the idea of meritocracy. They knew on one level what the right answer was or at least what they thought I wanted to hear. But, because they didn't own it, they didn't really believe it, so they continued defending the idea. In the prison this was very different. The inmates would often defend the idea of meritocracy and seemed to truly believe it to be true. For instance, one of the more popular articles we read was called, "Prison as a Member of the Family" (LeBlanc, 2003). In this article we learn about two young teenagers who fall in love, have children, commit crimes, go to prison, and struggle with challenges related to relationships between loved ones, friends, and family. The story is compelling and complicated and all of the students in my class loved reading it and talking about it. Long after we read it they were still bringing it up and making connections to the situations and people in the article. In one of the class discussions related to this article one of the typical college students asked the inmates in the large group setting, "Why did you choose to go this route that would get you locked up? You all talk about how education is important but that is not how you acted. I am studying to be a teacher. What can you tell me, what can I do to help kids like you not wind up in jail?" Almost immediately one of the inmates spoke up, "Teachers can't do nothin'. I know for me, it was all me. I didn't want to be in school and there wasn't nothin' teachers could have done. It's not the teachers fault if kids don't wanna learn."

Many of the inmates agreed, it was their fault and nothing that anyone could have done. But what happened next both made me proud and broke my heart. A few of the typical students, lead by the girl who asked the question in the first place, started challenging the idea that 'there wasn't nothin' teachers could have done". The conversation moved to the responsibility of adults to help children make good decisions, the impact of stress and poverty on decision-making, and the lack of options in many under resourced areas. That evening I wrote,

It was great seeing one of the college students ask a hard question and spur a great discussion. And, I was so happy when she challenged the notion that [Sean] was completely responsible for his failures in school. At first, I was so proud to hear my college students talk about societal inequities and the failures of the public school system. And then, I realized that the inmate students had stopped speaking. They were silent. All of a sudden I wondered if some of them had just realized how they had been cheated. Was this silence just because they lost track of the discussion or it was over their heads. Or, was it because they just now realized that they never had a chance, that they deserved a degree of protection and support and they did not get it? I saw their faces, still, silent, and felt really sad." (instructor journal). 
It seemed that when the typical college students sat side by side with and built relationships with people who had clearly experienced oppression they were able to see more clearly. For the inmates, they often expressed that this was the first time they had open dialogue about issues related to race, power, and privilege and that it challenged their notions of whiteness, college, college students, and their own future.

In her final reflection Liz, the student who asked the question, wrote, “...none of us were familiar with one another yet we all had such strong and different opinions and were not afraid to share them. Ultimately, everyone in the group had a different answer to the question and we varied in philosophy and reasoning through most of the conversation. The best part of the conversation was that in the end, everyone tweaked their reasoning at least a little bit because of someone that someone else in the group said. This became a habit that would continue week to week, where after discussing something, we would change each other's minds or at least make the other see a different side of a situation."

Other perspective shifts came from typical college students who expected to come to the course and have their beliefs verified. Instead, many of them recognized the mismatch between what they had believed and what they actually experienced. One of these students reflected in his very last paper,

I learned from this whole experience that I cannot really judge anyone the way I have been. The guys in the class were just regular guys that have made a mistake. I realize that some of them have made more than one mistake and are not really good guys, but they are just regular people. The media paints them as savages and animals and literature does not help with this image. Criminology texts do even worse by portraying them as numbers and percentages and statistics. Even though some of them have lost their right to be considered a trusted citizen, in the media they almost seem to lose their right to be people. I understand that if you commit too many heinous offenses, you should be labeled a monster and put away, but these guys do not seem like monsters, at least inside the classroom. (Jon, Final Reflection)

Jon's reflection shows his struggle. He seems to be trying to reconcile these men he has gotten to know with what he has been taught. He seems to be holding on to his beliefs to some degree - "I understand that if you commit too many heinous offenses, you should be labeled a monster..." and at the same time questioning whether these characterizations are accurate - "...these guys don't seem like monsters..." For Jon and the other students who plan to work in the criminal justice system these are important ideas for which to struggle.

During the very last class we took some time to talk about the class itself and acknowledge one another in a positive way. I asked each of the typical college students to jot down something positive to share about their group members. This was not required but many of them did it. On that last day, I thanked everyone for their presence and participation, acknowledged our class members who had been transferred to other facilities, and asked for them to share something they liked about the class or to acknowledge a classmate. The typical college students were prepared with things to say and they jumped right in. The inmate students were not prepared but they also spoke up, thanked specific group members and talked about what they learned in class. One particularly poignant moment came after Liz read a prepared statement acknowledging one of her inmate group members. Her voice shook as she told him that she was proud of his work and impressed with the way he spoke about his son. In about three minutes with a shaky voice and no eye contact she prompted a few tears across the classroom. The student to whom she was speaking looked at me and said, "I know I can get in trouble for this but I don't care, I am giving her a hug." He got up and gave her a hug, the class giggled and we moved on. The biggest surprise for me was that almost every single inmate student talked about how they valued what they learned about communication. Until that moment I thought the course content really mattered. I still think it mattered a little bit. But mostly, it was just something to talk about, something to have real conversations about. And, it seemed the value for the inmate students was just that. In his final reflection, Will wrote,

While in this class I have learned how to communicate with others without getting upset when someone does not share the same views. Before I would get upset and shut down. But now I give my opinion and listen to the other person's opinion. So with this new communication skill I could use to help me find and keep a job. I could also use this skill in a lot of things when the day I go home. (Will, inmate student, final reflection)

This sentiment was echoed again and again during that final discussion and in every one of the final reflections that was turned in by the inmate students. A good friend of mine likes to share a story from a 1980s play called The Search for Intelligent Life in the Universe. In that play, aliens come to Earth and find a bag lady who teaches them all about Earth and being human. She shows them Andy Warhol's Campbell's Soup painting and a can of Campbell's soup and tells them which is "soup" and which is "art". Later in the play she takes them to a Broadway play. She notices that the aliens are watching the audience and not the action on the stage and she tries to get them to switch their attention to the stage. They tell her that the action on stage is the "soup" and the audience reaction is the "art". Recently when I was telling my friend about my experiences in the prison and he brought this up again. He said the course content was the "soup," but what happened in class was the "art".

\section{What's happening?}

This paper is meant to serve as a counter narrative to the stories that are often heard and believed about incarcerated youth of color. This piece is a story aimed at giving voice to a group of men who have been silenced through incarceration. This is also a narrative that sug- 
gests that having groups from disparate backgrounds work together in a meaningful way can support perspective change for both groups.

This narrative also recognizes that oppression is multidimensional and that oppression is not a result of racial bias alone. In this case, we look closely at the intersection between the individual and school, the individual and society, and individuals from disparate cultural backgrounds (gender, religion, education, socioeconomic status, etc.) and how they relate to one another. Last, critical race theory challenges us to examine how power and privilege mediate the differential experiences of our participants. Leading with a social justice orientation, the classroom experiences described here demonstrate what happens when you teach about racism and white privilege explicitly, provide opportunities for students to have a true voice and become advocates for themselves, and integrate authentic learning opportunities to meet objectives.

As an institution supporting the transition of our students between adolescence and adulthood, we would be remiss to ignore the developmental implications of these issues. Bronfenbrenner's Ecological Systems theory (Bronfenbrenner, 1988, 1989) provides a structure for which to consider the relationships between a developing person and his immediate environment (i.e. school, family) and institutional patterns of culture. At the microsystem level traditional college students are experiencing stress with school and the students from the prison are experiencing a myriad of stressors (i.e. low expectations, preparation gaps, social isolation). Both groups of students may be experiencing other stressors as well (i.e. family, financial, emotional). We know that financial difficulties, in particular, inhibit success across all demographic groups. These competing demands are often at odds with one another at the precise times when students are in need of support. At the macro system, the culture of the prison education system is not welcoming to either the traditional or inmate students. While these students may see the experience through very different lenses, they all see something less than optimal. Also, the prison education attempts to function from an Essentialist point of view - stressing the core skills needed in literacy and math. However, in practice, the educational opportunities for the inmates often do not even support learning the basics. The inmates who have participated in the prison education systems up until this point have seen sparse, teacher-centered classrooms, where there are few opportunities for individualized instruction or remediation. These programs do not offer the best match of modality and content for all students. What we teach and how we teach it sends a message about our institutional pattern of culture and feeds into the hidden curriculum that is a key variable in the macro system.

Critical race theory helps to frame how race mediates the experiences for all of the students in the class. In particular, the principle of interest convergence is relevant in this work. Interest convergence is a term that was first introduced by Derrick Bell (1980). He posited that when de jure segregation was abolished in the
United States with the Brown v BOE case it was not because of a moral imperative but rather the result of the convergence of interests of both the Black Civil Rights movement and the interests of elite Whites. Both the prison system and the college supported the course described in this study. The interests of the college in providing an opportunity to visit a prison and engage with "the other" converged with the interest of the prison to provide meaningful education experiences for some of the inmates.

While the typical college students would have examined issues of race and privilege in an on campus class, discussing these same issues with classmates who have a much different lived experience changes the dynamic. For instance, when this course is taught on campus with only typical college students, we spend a lot of time discussing the neo-liberal push to ignore or transcend race and ethnicity (colorblindness). Typical college students often arrive with a restrictive view of equality. In a restrictive view the belief is that we all have the same opportunities and whether or not we take advantage of them has nothing to do with race or ethnicity. I hope to help students embrace a more expansive view, of equity more than equality. In the course where inmates and typical students studied together, White students thought twice about blaming any individual for their current circumstance. At first, this hesitation came from fear of being labeled a racist. As relationships developed, the hesitation arose because of the realization that if he and the person sitting next to him had been switched at birth, born just ten miles away from where they were actually born, both lives could be very different. It became clear to them very quickly that no matter the intention of the public school system, the outcomes were not good for many children. That reality, one that sees the importance of outcomes, is the expansive view that is needed.

Incorporating social justice pedagogy into the classroom benefits all learners as it effectively prepares students for the complex society that we live in. While there are many examples of teachers embracing social justice pedagogy (Nieto, 2000), there are still challenges to teaching social justice particularly to students who are white and middle class. One challenge is the lack of a cohesive definition of what social justice means and what it looks like in the classroom (Dover, 2009). Students who are white middle class often lack knowledge about and display resistance to social justice issues (Sleeter, 2001). This dissonance is often due to the fact that many white students have a deficit of their own, having attended mainly mono-cultural schools (Fuller, 1992) where a social justice orientation was not evident. Having the lived experience of being oppressed did not always result in a true understanding of that experience or of social justice more broadly.

\section{What now?}

As a teacher educator I have changed my perspective on how to support critical reflection and authentic learning. Many of my typical college students seem very committed to teaching in the most under- 
resourced schools. The children served in those schools come with a myriad of challenges that need attention if they are to be successful. First and foremost I have come to believe, now more than ever, that opportunities for open and honest dialogue and relationship building are essential between people from disparate backgrounds. It is too easy to "talk the talk" when you never have to "walk the walk" and it was not until I saw the difference between my on campus class and my prison class that I saw this difference so clearly. Schools of Education must provide opportunities beyond fieldwork where future teachers go in to practice teaching. Future teachers need to be integrated into the community where they work. Opportunities to get to know parents, children, and other community members are essential.

Also, the current model for many education programs in prisons is not working (Farabee, 2005). On most days a prison classroom will have several students working on completely different tasks and one teacher trying to help each inmate. The students from my class shared that there were times when they got stuck on a problem or with their writing and sat with nothing to do for 20 minutes or more while they waited for the teacher to make their way back to them. They felt that the day classes were a waste of time and were not preparing them for life outside of prison or a General Equivalency Diploma $[\mathrm{GED}]^{1}$. To be sure, teachers in the prison system have a difficult task. In my class I had students who wrote at a college level and others who could barely string a sentence together. Differentiating for a range of students like that is no easy task. However, prison education might benefit from expanding past the basics of math and reading and making an explicit effort at improving students' ability to communicate, not just in writing but also interpersonally.

In 1995, Hart and Risley conducted a study where they looked at exposure to language and vocabulary between three types of families - professional, working -class, and families on welfare. Their analysis showed that in a 100-hour week, the average 4 year old in a family on welfare might have " 13 million fewer words of cumulative experience than the child in a workingclass family." And among those words children from lower socio-economic status households hear far fewer encouraging words and far more prohibitions or discouragements. We know that many of our incarcerated youth are coming from low resourced households and neighborhoods. They may not have gotten the support at home that would foster adaptive communication skills. Connell and Prinz (2002) wrote about how high quality relationships with caregivers are essential for school readiness and social skill development in young children. Given the possibility that incarcerated youth did not experience high quality interactions, exposure to rich and varied vocabulary, and encouragements that outweighed discouragements, prison systems might consider remediation in these areas essential. Considering their positive impact on school readiness in young children, I cannot help but wonder if practicing adaptive social skills as an adult can support relationship readiness and job readiness in a similar way.

\section{References}

Bronfenbrenner, U. (1988). Interacting systems in human development: Research paradigms, present and future. In Bolger, N., Caspi, A., Downey, G., Moorehouse, M. (Eds.) Persons in Context: Developmental Processes. Cambridge, UK: University Press.

Bronfenbrenner, U. (1989). Ecological systems theory. In Vasta, R. (Ed.) Six Theories of Child Development: Revised formulations and Current Issues. Vol. 6. Greenwich, CT: JAI Press.

Connell, C. M. \& Prinz, R. J. (2005). The Impact of Childcare and Parent-Child Interactions on School Readiness and Social Skills Development for LowIncome African American Children. Journal of School Psychology, 40(2), 177-193.

Dover, A. G. (2009). Teaching for Social Justice and K-12 student outcomes: A conceptual framework and research review. Equity and Excellence in Education, 42(4), 506-52.

Farabee, D. (2005). Rethinking rehabilitation: Why can't we reform our criminals? Washington, DC: AEI Press.

Fuller, M. L. (1992). Teacher education programs and increasing minority school populations: An educational mismatch. In C. A. Grant (Ed.) Research and multicultural education: From margins to the main stream. London, UK: Falmer.

Hart, B. \& Risley, T. R. (1995). The Early Catastrophe: The 30 Million Word Gap by Age 3. Meaningful Differences in the Everyday Experiences of Young American Children. Baltimore, MD: Brookes.

Martinson, R. (1974). What Works? - Questions and Answers About Prison Reform. The Public Interest, 35, 22-54.

Pratt, M. L. (1991). Arts of the Contact Zone. Profession '91. New York, NY: MLA.

Sleeter, C. E. (2001). Preparing teachers for culturally diverse schools: Research and the overwhelming presence of whiteness. Journal of Teacher Education, 52(2), 94-106.

\footnotetext{
${ }^{1}$ The General Equivalency Diploma [GED] is a high school equivalency test that assesses knowledge in Science, Social Studies, Math, and Language Arts. The GED is intended to help adults qualify for college and employment.

Tabitha Dell'Angelo is an Assistant Professor at The College of New Jersey. She received her Ph.D. from the University of Pennsylvania in 2009. Her research interests focus on cultural identity development for pre-service teachers and applying social justice frameworks to K-12 classrooms.
} 